\title{
Diagnosis of growth hormone deficiency in adults by testing with GHRP-6 alone or in combination with GHRH: comparison with the insulin tolerance test
}

\author{
Stephan Petersenn, Roman Jung ${ }^{1}$ and Frank U Beil \\ Department of Medicine and ${ }^{1}$ Department of Clinical Chemistry, University Clinic Eppendorf, University of Hamburg, 20251 Hamburg, Germany \\ (Correspondence should be addressed to S Petersenn, Division of Endocrinology, Medical Center, University of Essen, Hufelandstr. 55, 45122 Essen, \\ Germany; Email: stephan.petersenn@uni-essen.de)
}

\begin{abstract}
Objective: The diagnosis of GH deficiency in adults should be made using provocative testing of GH secretion. The insulin tolerance test (ITT) is recommended as the gold standard investigation. Because of the risk of serious complications, patients with epilepsy or known ischemic heart disease should not undergo this test. GHRP-6 is a synthetic hexapeptide that releases GH by binding to specific hypothalamic and pituitary receptors. We assessed the diagnostic capability of $\mathrm{GH}$ stimulation by GHRP-6 alone or in combination with GHRH in comparison to the results of an ITT.

Design: Twenty patients underwent an ITT for suspected pituitary or adrenal disease. Either GHRP-6 $(1 \mu \mathrm{g} / \mathrm{kg})$ alone, or GHRP-6 in combination with GHRH $(1 \mu \mathrm{g} / \mathrm{kg})$ were administered on different days. Blood samples were obtained during a subsequent 90-min period for measurement of GH. Results: Ten patients had a GH peak response of less than $3 \mu \mathrm{g} / \mathrm{l}$ during ITT and were considered growth hormone deficient (GHD). The GH mean peak ( \pm S.E.M., range) in this group was $0.7 \mu \mathrm{g} / \mathrm{l}$ $( \pm 0.3,0.1-2.9)$ compared with $14.5 \mu \mathrm{g} / \mathrm{l}( \pm 3.5,3.8-40.8)$ in the group of patients with a $\mathrm{GH}$ peak response of more than $3 \mu \mathrm{g} / \mathrm{l}$ (growth hormone sufficient (GS)). For the GHRP-6 test, the GH mean peak was $1.3 \mu \mathrm{g} / \mathrm{l}( \pm 0.6,0.1-6.7)$ in the GHD group versus $25.7 \mu \mathrm{g} / \mathrm{l}( \pm 5.5,7.7-54.2)$ in the GS group. After GHRP-6 + GHRH, the GH mean peaks were $4.0 \mu \mathrm{g} / \mathrm{l}( \pm 1.3,0.2-11.9)$ versus $54.7 \mu \mathrm{g} / \mathrm{l}( \pm 11.1,13.9-136.0)$ respectively. During administration of GHRP-6, the only side effects observed were flush symptoms.

Conclusions: Peak GH levels below $7 \mu \mathrm{g} / \mathrm{l}$ for the GHRP- 6 test and below $13 \mu \mathrm{g} / \mathrm{l}$ for the combined GHRP-6 + GHRH test identified all patients with GH deficiency correctly as defined by ITT. The results suggest that testing with GHRP-6 or GHRP- 6 + GHRH is as sensitive and specific as an ITT for the diagnosis of adult $\mathrm{GH}$ deficiency.
\end{abstract}

European Journal of Endocrinology 146 667-672

\section{Introduction}

Growth hormone $(\mathrm{GH})$ deficiency in adults is thought to result in abnormalities of body composition, reduced physical performance, impaired psychological wellbeing, and premature mortality (1). Replacement of GH may improve impaired health in such patients. Therefore, patients with evidence of hypothalamicpituitary disease, subjects who have received cranial irradiation, or patients with childhood onset of $\mathrm{GH}$ deficiency should be evaluated for GH deficiency (2). The diagnosis of GH deficiency is established by provocative testing. The insulin tolerance test (ITT) has been indicated as the test of choice. Severe GH deficiency has been defined by a GH peak of less than the arbitrary cut-off of $3 \mu \mathrm{g} / \mathrm{l}$ (2). The test is contraindicated in patients with electrocardiographic evidence or history of ischemic heart disease, or in patients with seizure disorders. It should only be performed in experienced endocrine units and requires careful supervision that makes it very expensive and inappropriate as a screening procedure. Whereas adult patients with hypothalamic disease and one or more additional pituitary hormone deficits require only one provocative test of $\mathrm{GH}$ secretion, it is recommended that a second biochemical test of GH status is performed to establish the diagnosis of isolated GH deficiency (2). For such patients and for patients with contraindications to the ITT it seems necessary to establish other stimulatory tests with appropriate cut-offs.

GH secretion by the anterior pituitary is under complex control. Small synthetic molecules termed GH secretagogues (GHS) act on the pituitary and the hypothalamus to stimulate and amplify pulsatile GH release 
(3). These compounds appear to mimic a putative endogenous ligand which activates a receptor distinct from that of GH-releasing hormone (GHRH) and somatostatin (4). The function of this receptor is probably critical for regulation of normal GH secretion. Analogs studied so far include GHRP-2, GHRP-6, Hexarelin and MK-0677 (5). An endogenous specific ligand of 28 amino acids has recently been purified from rat stomach; it has been termed 'ghrelin' (6). GHS may offer practical diagnostic and therapeutic value in humans. They show potent and reproducible $\mathrm{GH}_{-}$ releasing activity, release more $\mathrm{GH}$ than $\mathrm{GHRH}$, and truly synergizes with GHRH (7). We compared GH provocation by GHRP-6 alone or by GHRP-6 plus GHRH with an ITT for the diagnosis of GH deficiency in adults.

\section{Subjects and methods}

\section{Patients}

Twenty patients (11 male and 9 women, aged 19-66 years, BMI $19.8-33.9 \mathrm{~kg} / \mathrm{m}^{2}$ ) underwent an ITT at our department because of suspected pituitary or adrenal disease (Table 1). Thirteen patients had a history of tumors in the pituitary area (five non-functioning adenomas, three corticotropic adenomas, one prolactinoma, two pituitary cysts, one meningioma, one craniopharyngeoma), and four patients had a history of pituitary hormone deficiency (two congenital, one traumatic, one diabetes insipidus). Two patients had a diagnosis of short stature, and one patient was operated on for an adrenal mass. Some of these patients had received previous treatment by operation or radiation. All patients with pituitary insufficiencies other than $\mathrm{GH}$ had been receiving optimal replacement therapy for at least 3 months. No patients had received recombinant $\mathrm{GH}$ for at least 1 year before testing.

The local ethics committee approved the study proto$\mathrm{col}$, and all subjects gave their informed written consent to participate in the study.

\section{Methods}

Patients underwent an ITT by injection of 0.1$0.15 \mathrm{IU} / \mathrm{kg}$ of regular insulin (Actrapid Novo Nordisk, Mainz, Germany) to achieve blood glucose levels below $40 \mathrm{mg} / \mathrm{l}$ and until symptoms of hypoglycemia developed. All patients underwent testing with GHRP-6 (CLINALFA AG, Läufelfingen, Switzerland; $1 \mu \mathrm{g} / \mathrm{kg}$; i.v. at $0 \mathrm{~min}$ ) alone and in combination with GHRH (Ferring GmbH, Kiel, Germany; $1 \mu \mathrm{g} / \mathrm{kg}$; i.v. at $0 \mathrm{~min})$. All tests were performed in the morning after an overnight fast, at least 1 day apart. Blood samples for $\mathrm{GH}$ assay were taken at $0,15,30,45,60$ and $90 \mathrm{~min}$. Basal IGF-I levels were determined in all patients. Corticotropic function was assessed by ITT, gonadotropic and thyrotropic functions were determined by provocation with gonadotrophin-releasing hormone $(\mathrm{GnRH})$ and thyrotrophin-releasing hormone

Table 1 Clinical characteristics of 20 patients with suspicion of pituitary or adrenal disease tested by ITT. Sufficient (s) or insufficient (i) pituitary hormone function is indicated, as determined by provocation tests. IGF-I values at the time of testing are shown.

\begin{tabular}{|c|c|c|c|c|c|c|c|c|c|}
\hline No & Sex & Age & BMI & Diagnosis & GH & Cortisol & TSH & LH/FSH & IGF-I $(\mu \mathrm{g} / \mathrm{l})$ \\
\hline 1 & $\mathrm{~m}$ & 31 & 20.8 & Cushing $\rightarrow$ OP & $\mathrm{s}$ & i & $\mathrm{s}$ & $\mathrm{s}$ & 153 \\
\hline 2 & $f$ & 66 & 20.1 & $\mathrm{NFA} \rightarrow \mathrm{OP}$ & $\mathrm{s}$ & $\mathrm{s}$ & $\mathrm{s}$ & $\mathrm{s}$ & 79 \\
\hline 3 & $f$ & 19 & 19.8 & Diabetes insipidus & $\mathrm{s}$ & $\mathrm{s}$ & $\mathrm{s}$ & $\mathrm{s}$ & 451 \\
\hline 4 & $f$ & 33 & 20.3 & Adrenal adenoma $\rightarrow$ OP & $\mathrm{s}$ & $\mathrm{s}$ & $\mathrm{s}$ & $\mathrm{s}$ & 316 \\
\hline 5 & $\mathrm{~m}$ & 52 & 27.7 & NFA & $\mathrm{s}$ & $\mathrm{s}$ & $\mathrm{s}$ & $\mathrm{s}$ & 359 \\
\hline 6 & $\mathrm{~m}$ & 55 & 27.8 & Prolactinoma & $\mathrm{s}$ & $\mathrm{s}$ & $\mathrm{s}$ & i & 290 \\
\hline 8 & $f$ & 43 & 23.1 & NFA & $\mathrm{s}$ & $\mathrm{s}$ & $\mathrm{s}$ & $\mathrm{s}$ & 43 \\
\hline 9 & $\mathrm{~m}$ & 27 & 19.9 & Short stature & $\mathrm{s}$ & $\mathrm{s}$ & $\mathrm{s}$ & $\mathrm{s}$ & 247 \\
\hline \multirow[t]{2}{*}{10} & $\mathrm{~m}$ & 57 & 25.6 & Short stature & $\mathrm{s}$ & $\mathrm{s}$ & $\mathrm{s}$ & $\mathrm{s}$ & 203 \\
\hline & $6 / 4$ & 43 & 23.0 & & $0 / 10$ & $1 / 10$ & $0 / 10$ & $1 / 10$ & 231 \\
\hline 11 & $\mathrm{~m}$ & 32 & 23.2 & Trauma & i & i & $\mathrm{i}$ & i & 15 \\
\hline 12 & $f$ & 41 & 26.2 & Congenital PHD & i & i & $\mathrm{i}$ & $\mathrm{i}$ & 16 \\
\hline 13 & $f$ & 64 & 25.1 & Cushing $\rightarrow$ radiation & i & $\mathrm{s}$ & $\mathrm{i}$ & $\mathrm{i}$ & 74 \\
\hline 15 & $f$ & 60 & 33.4 & $\mathrm{NFA} \rightarrow \mathrm{OP}$ & $\mathrm{i}$ & $\mathrm{i}$ & $\mathrm{i}$ & $\mathrm{i}$ & 36 \\
\hline 16 & $f$ & 37 & 33.9 & Cyst $\rightarrow$ OP & i & i & $\mathrm{i}$ & i & 15 \\
\hline 17 & $\mathrm{~m}$ & 55 & 27.4 & Craniopharyngioma & i & $\mathrm{s}$ & $\mathrm{i}$ & i & 116 \\
\hline 18 & $\mathrm{~m}$ & 27 & 24.9 & Congenital PHD & $\mathrm{i}$ & $\mathrm{s}$ & $\mathrm{s}$ & $\mathrm{i}$ & 18 \\
\hline 19 & $f$ & 50 & 28.3 & Meningioma & i & $\mathrm{s}$ & $\mathrm{s}$ & $\mathrm{s}$ & 131 \\
\hline \multirow[t]{2}{*}{20} & $\mathrm{~m}$ & 47 & 27.7 & Cushing $\rightarrow$ OP + radiation & i & $\mathrm{s}$ & i & i & 145 \\
\hline & $5 / 5$ & 47 & 27.4 & & $10 / 10$ & $5 / 10$ & $8 / 10$ & $9 / 10$ & 65 \\
\hline
\end{tabular}

BMI, body mass index; TSH, thyrotropin; LH, luteinizing hormone; FSH, follicle-stimulating hormone; OP, operation; NFA, non-functioning adenoma; PHD, partial hormone deficiency. 
(TRH) respectively. After centrifugation, plasma samples were stored at $-20^{\circ} \mathrm{C}$ until analysis.

Serum GH levels ( $\mu$ g per litre) were assayed at each time point by RIA (CIS bio international, Gif-SureYvette Cedex, France). The lower detection limit was assessed to be $0.04 \mu \mathrm{g} / \mathrm{l}$. Intra-assay variations as coefficient of variation for various $\mathrm{GH}$ values were $2.4 \%$ (3.46 $\mu \mathrm{g} / \mathrm{l}), 2.8 \%(7.3 \mu \mathrm{g} / \mathrm{l})$ and $2.3 \% \quad(47.4 \mu \mathrm{g} / \mathrm{l})$. Inter-assay variations were $4.2 \% \quad(3.3 \mu \mathrm{g} / \mathrm{l}), 3.2 \%$ $(7.1 \mu \mathrm{g} / \mathrm{l})$ and $4.0 \%(45.5 \mu \mathrm{g} / \mathrm{l})$. Normal values of spontaneous GH secretion were obtained by the manufacturer of the assay from presumed healthy adult subjects of both sexes. All values were in the $0-10 \mu \mathrm{g} / \mathrm{l}$ range, and 93.8\% were below $7 \mu \mathrm{g} / \mathrm{l}$. Basal serum insulin-like growth factor-I (IGF-I) levels ( $\mu$ g per liter) were determined by chemiluminescence immunoassay (Nichols Institute Diagnostics, San Juan Capistrano, CA, USA). The analytical sensitivity of the assay was determined as $6 \mu \mathrm{g} / \mathrm{l}$. Intra-assay variations as coefficient of variation for various IGF-I values were $4.8 \%$ $(63 \mu \mathrm{g} / \mathrm{l}), \quad 5.2 \% \quad(208 \mu \mathrm{g} / \mathrm{l})$ and $4.4 \% \quad(766 \mu \mathrm{g} / \mathrm{l})$. Inter-assay variations were $7.1 \% \quad(62 \mu \mathrm{g} / \mathrm{l}), \quad 5.7 \%$ $(215 \mu \mathrm{g} / \mathrm{l})$ and $7.4 \%(811 \mu \mathrm{g} / \mathrm{l})$. Normal values for adult IGF-I values in our laboratory were 182$780 \mu \mathrm{g} / \mathrm{l} \quad(16-24$ years $), \quad 114-492 \mu \mathrm{g} / \mathrm{l} \quad(25-39$ years), 90-360 $\mu \mathrm{g} / \mathrm{l}(40-54$ years) and $71-290 \mu \mathrm{g} / \mathrm{l}$ ( $55+$ years), as provided by the manufacturer.

Area under the curve (AUC) values were calculated by use of GraphPad Prism 3.0 software. Results (mean \pm s.E.M.) are expressed as absolute values for GH as well as for IGF-I. Statistical analysis was performed by Mann-Whitney test where appropriate. GraphPad Prism 3.0 software was used for analysis of correlation.

\section{Results}

\section{ITT}

Twenty patients with suspected pituitary or adrenal disease were included in this study. Provocation by hypoglycemia induced a marked GH release in ten subjects with a $\mathrm{GH}$ peak response of more than $3 \mu \mathrm{g} / \mathrm{l}$ (growth hormone sufficient (GS)) (Fig. 1a). Ten patients with a GH peak response of less than $3 \mu \mathrm{g} / \mathrm{l}$ were considered GH deficient (GHD) following the recommendations of a recent consensus statement (2). Elevated mean GH levels were observed 30-90 min after administration of insulin for the GS subjects as expected, whereas mean $\mathrm{GH}$ levels remained virtually unchanged at all time points for the GHD patients (Fig. $2 a$ ). The GH mean peak ( \pm S.E.M., range) was $0.7 \mu \mathrm{g} / \mathrm{l}( \pm 0.3,0.1-$ $2.9)$ in GHD patients, significantly lower $(P<$ $0.0001)$ as compared with $14.5 \mu \mathrm{g} / \mathrm{l}( \pm 3.5,3.8-$ 40.8) in GS subjects. Individual peak responses occurred at varying times (three patients after $30 \mathrm{~min}$, five patients after $45 \mathrm{~min}$, ten patients after $60 \mathrm{~min}$, two patients after $90 \mathrm{~min}$ ).
Calculation of the AUC revealed an overlap between the GHD and the GS group (Fig. $1 b$ ). In all GHD patients the AUC was $<200 \mu \mathrm{g} / \mathrm{l}$ per $90 \mathrm{~min}$ whereas in nine of ten GS subjects it was $>200 \mu \mathrm{g} / \mathrm{l}$ per $90 \mathrm{~min}$. Choosing an arbitrary cut-off of $200 \mu \mathrm{g} / \mathrm{l}$ per $90 \mathrm{~min}$ to define $\mathrm{GH}$ deficiency, one subject defined as non-GHD using the $\mathrm{GH}$ peak data was classified as GHD. The mean AUC ( \pm S.E.M., range) was $36.1 \mu \mathrm{g} / \mathrm{l}$ per $90 \mathrm{~min}( \pm 16.4$, 3.6-155.0) in the GHD group versus $713.4 \mu \mathrm{g} / \mathrm{l}$ per $90 \mathrm{~min}( \pm 167.5,91.3-1839.0)$ in the GS group $(P<0.0001)$.

\section{GHRP-6 test}

GHRP-6 alone was found to be more potent in releasing $\mathrm{GH}$ than hypoglycemia (Fig. 2b). The results were grouped according to the classification by ITT peak
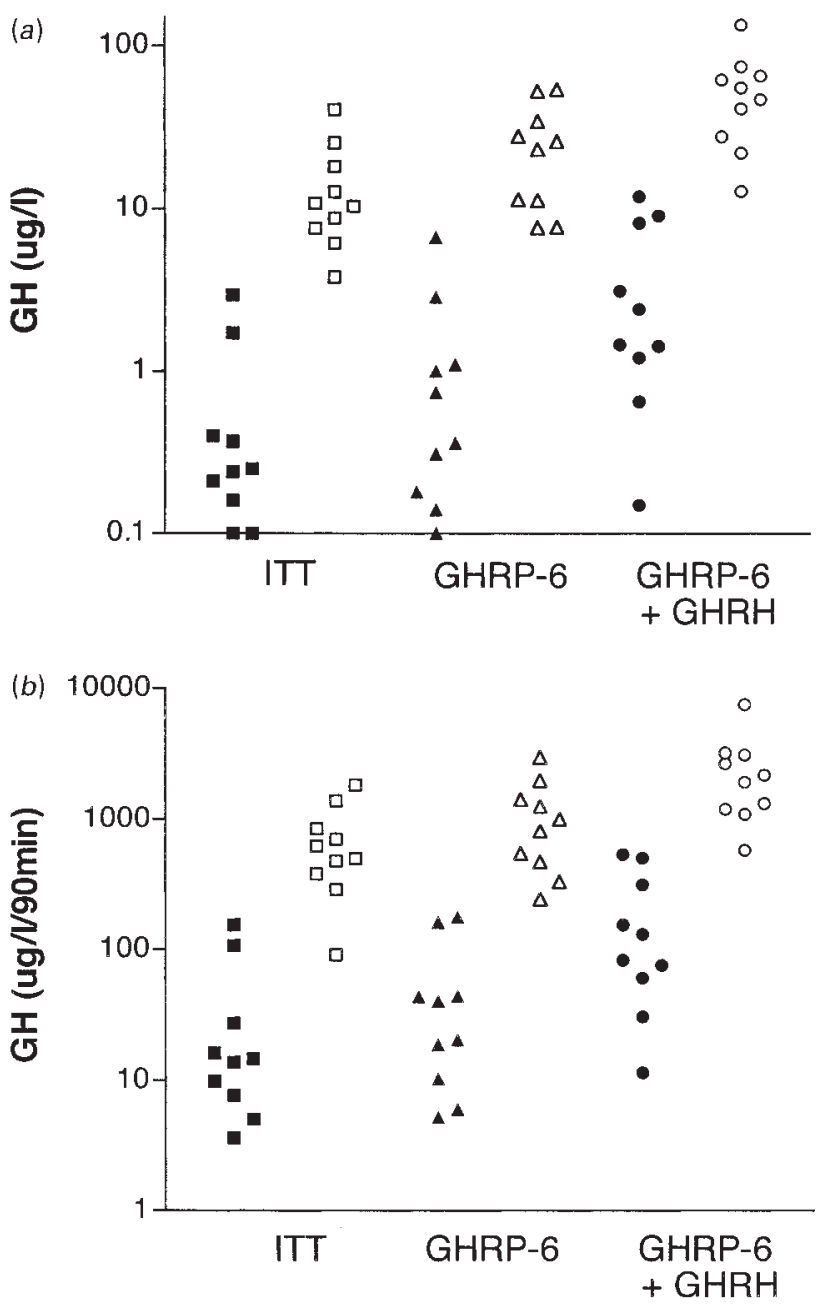

Figure 1 Analysis of GH (a) peak levels and $(b)$ AUC. Individual values during ITT (squares), GHRP-6 test (triangles), and GHRP$6+\mathrm{GHRH}$ test (circles) are demonstrated. Patients were defined as GHD (closed symbols)) or non-GHD (GS, open symbols) based on their $\mathrm{GH}$ peak response to hypoglycemia of $<3 \mu \mathrm{g} / \mathrm{l}$ or $>3 \mu \mathrm{g} / \mathrm{l}$. 

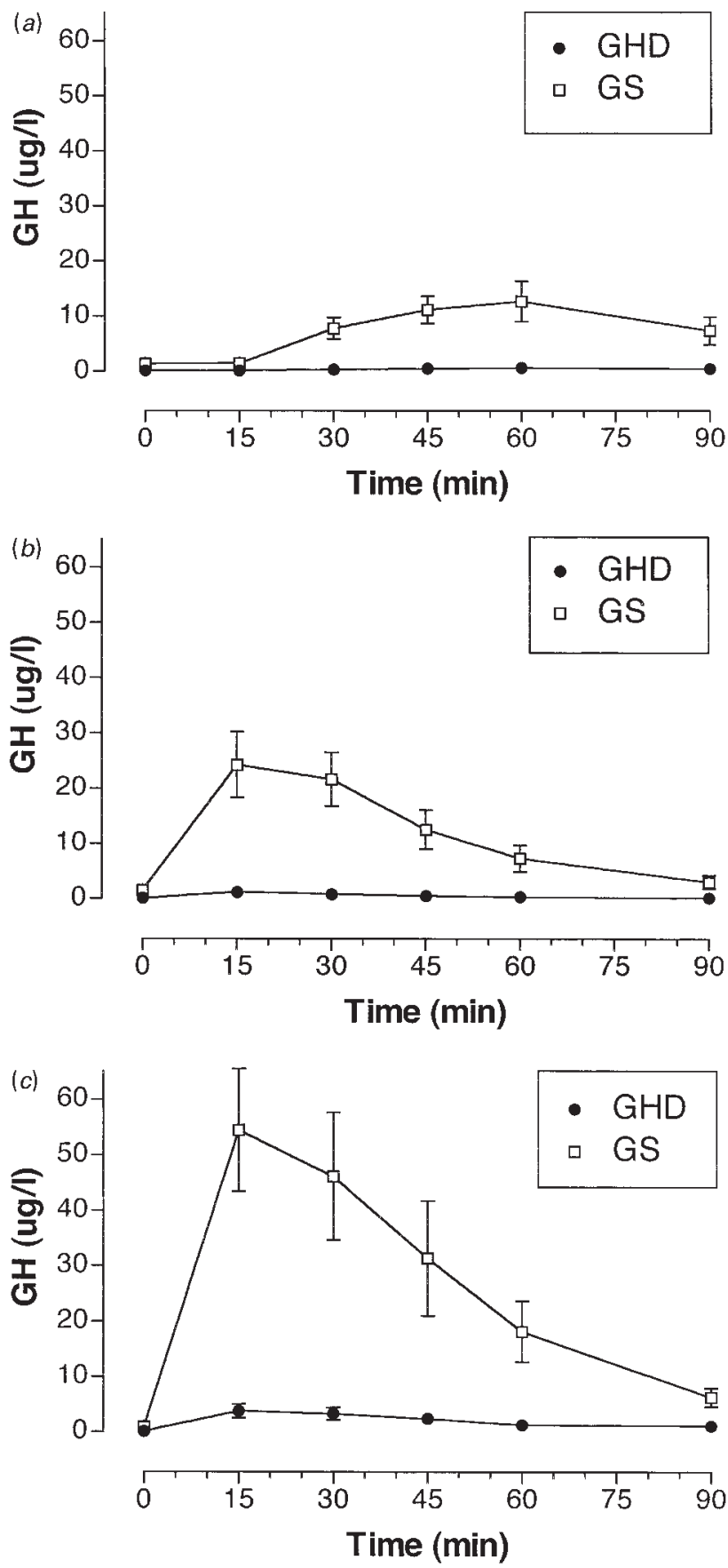

Figure 2 GH levels during (a) ITT, (b) GHRP-6 test, and (c) GHRP-6+GHRH test. Results (mean \pm S.E.M.) are shown for GHD (circles) or non-GHD subjects (GS, squares).

values. The GH mean peak ( \pm S.E.M., range) was $1.3 \mu \mathrm{g} / \mathrm{l}$ $( \pm 0.6,0.1-6.7)$ in the GHD group versus $25.7 \mu \mathrm{g} / \mathrm{l}$ $( \pm 5.5,7.7-54.2)$ in the GS group $(P<0.0001)$. Individual peaks occurred in 14 subjects at $15 \mathrm{~min}$, and in six subjects at $30 \mathrm{~min}$. The mean GH AUC $( \pm$ S.E.M., range $)$ was $52.9 \mu \mathrm{g} / \mathrm{l}$ per $90 \mathrm{~min}( \pm 20.1$, $5.2-177.1)$ in the GHD group versus $1102.7 \mu \mathrm{g} / \mathrm{l}$ per $90 \mathrm{~min}( \pm 269.2,243.6-2975.0)$ in the GS group $(P<0.0001)$.

There was a strong positive correlation between the $\mathrm{GH}$ peak responses during ITT and the GHRP-6 test (Fig. $3 a, r=0.87, P<0.0001$ ). Choosing an arbitrary cut-off of $7 \mu \mathrm{g} / \mathrm{l}$ for the $\mathrm{GH}$ peak levels, there was $100 \%$ concordance in the diagnosis of GH deficiency by both tests for all our subjects (Fig. 1a). In addition, an AUC below $200 \mu \mathrm{g} / \mathrm{l}$ per $90 \mathrm{~min}$ identified all patients with $\mathrm{GH}$ deficiency correctly as defined by GH peak response during ITT (Fig. 1b).
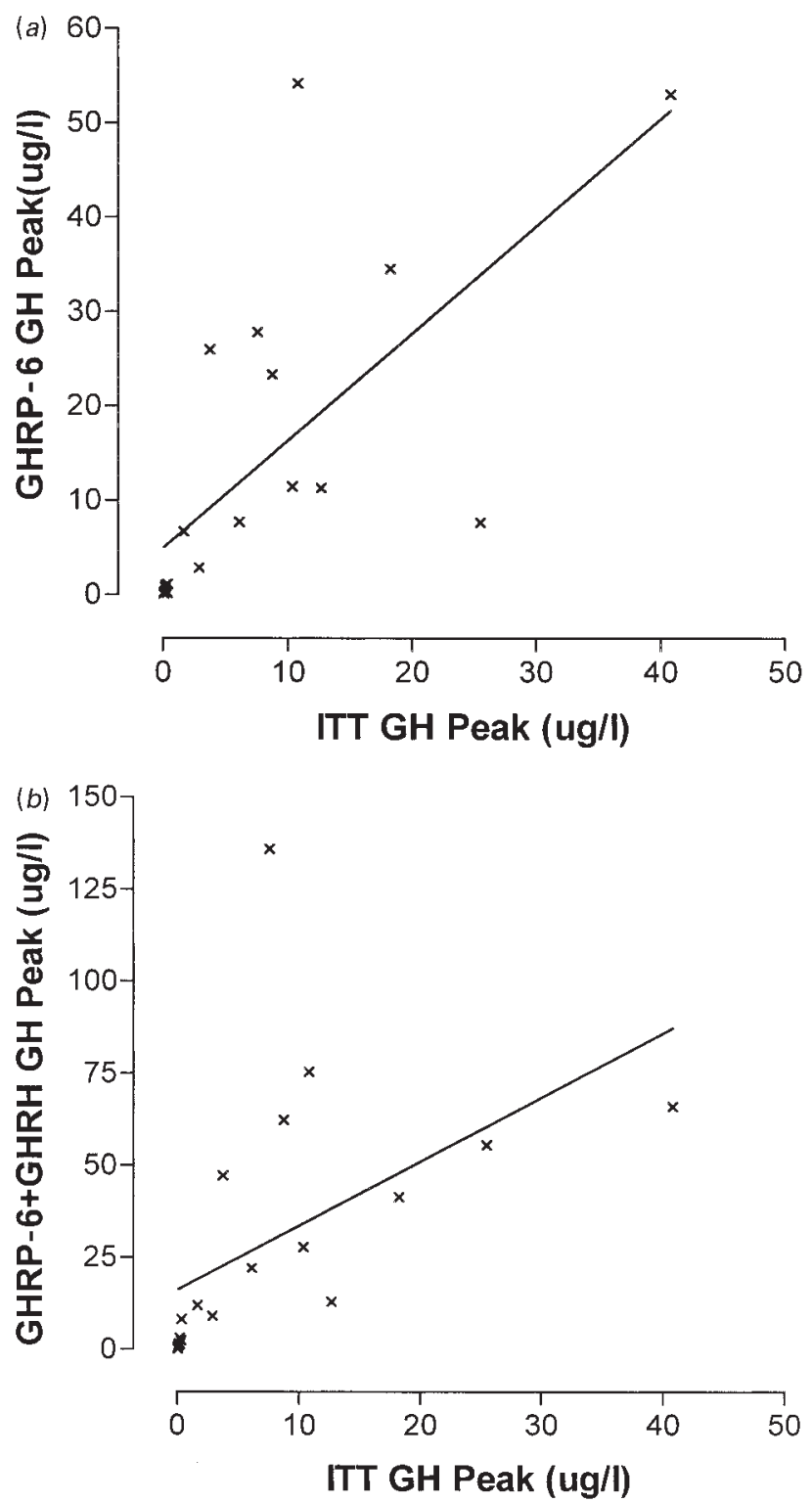

Figure 3 Individual GH peak levels during ITT in 20 subjects plotted against GH peaks during (a) GHRP-6 test and (b) GHRP$6+\mathrm{GHRH}$ test. Symbols for patients with very low $\mathrm{GH}$ levels overlay each other. 


\section{GHRP-6 + GHRH test}

Administration of GHRP-6 + GHRH caused a prompt release of $\mathrm{GH}$ (Fig. 2c). The GH mean peaks ( \pm S.E.M., range) were $4.0 \mu \mathrm{g} / \mathrm{l}( \pm 1.3,0.2-11.9)$ in the GHD group versus $54.7 \mu \mathrm{g} / \mathrm{l}( \pm 11.1,13.9-136.0)$ in the GS group $(P<0.0001)$. Individual peaks occurred in 17 subjects at $15 \mathrm{~min}$, and in three subjects at $30 \mathrm{~min}$. The mean AUC ( \pm s.E.M., range) was $190.6 \mu \mathrm{g} / \mathrm{l}$ per $90 \mathrm{~min}( \pm 61.4,11.4-536.9)$ in the GHD group versus $2491.8 \mu \mathrm{g} / \mathrm{l}$ per $90 \mathrm{~min}( \pm 629.3$, $578.0-7555.0)$ in the GS group $(P<0.0001)$.

As for the GHRP-6 test, there was a strong positive correlation between the $\mathrm{GH}$ peak responses during ITT and the GHRP-6 + GHRH test (Fig. $3 b, r=0.88$, $P<0.0001)$. Peak GH levels below $13 \mu \mathrm{g} / \mathrm{l}$ for the GHRP-6 + GHRH test identified all patients with GH deficiency as well as all patients with sufficient $\mathrm{GH}$ secretion correctly as defined by ITT (Fig. 1a). Choosing an arbitrary cut-off of $550 \mu \mathrm{g} / \mathrm{l}$ per $90 \mathrm{~min}$ for the AUC, all patients defined as GHD by $\mathrm{GH}$ peak response during ITT are correctly classified (Fig. 1b).

\section{Comparison to IGF-I}

The IGF-I levels (mean \pm s.E.M., range) in GHD patients $(65.2 \pm 16.4,15.0-145.0)$ were lower than those in GS subjects $(231.0 \pm 40.1,43.0-451.0)$ with some overlap between the two groups $(P<0.01)$. One subject with sufficient GH secretion had IGF-I levels below his normal age-related reference values. Five patients considered GHD by all provocation tests had normal agerelated IGF-I values, although two of them had IGF-I values at the very lower end of the reference range.

There was a strong positive correlation between the GH peak responses and IGF-I levels for the GHRP-6 test $(r=0.77, P<0.0001)$ as well as between $\mathrm{GH}$ peaks and IGF-I values for the GHRP-6 + GHRH test $(r=0.82, P<0.0001)$. For comparison, the correlation between GH peaks during ITT and IGF-I levels was calculated to be $0.73(P<0.001)$. Similar correlations between AUC and IGF-I were found for the GHRP-6 test $(r=0.78, P<0.0001)$ and for the GHRP-6 + GHRH test $(r=0.82, P<0.0001)$.

\section{Side effects}

During ITT, clinical intervention was necessary in three subjects because of severe symptoms of hypoglycemia. However, after administration of GHRP-6 or GHRP-6 $+\mathrm{GHRH}$, the only side effects observed consisted of mild flushing.

\section{Discussion}

The results of this study show that provocative tests using GHRP-6 alone or in combination with GHRH are reliable tools for the diagnosis of $\mathrm{GH}$ deficiency in adults. Peak GH levels below $7 \mu \mathrm{g} / \mathrm{l}$ for the GHRP-6 test and below $13 \mu \mathrm{g} / \mathrm{l}$ for the combined GHRP-6 + GHRH test were successful in identifying all patients with GH deficiency correctly as defined by ITT. Thus, with appropriate cut-off values, these tests are as sensitive and specific as the ITT that is considered the gold standard.

The only other study of a single GHS test for diagnosis of GH deficiency in adults was performed by Korbonits et al. (8). These authors used a different GHS (Hexarelin, $2 \mu \mathrm{g} / \mathrm{kg}$ ) to investigate the $\mathrm{GH}$ response in 19 patients with possible pituitary disease. Seven patients were found to be severely GHD defined by ITT. For Hexarelin testing, the authors established a lower limit of the normal GH response of $13.8 \mu \mathrm{g} / \mathrm{l}$. Because of different substances and dosages, stimulated $\mathrm{GH}$ values cannot be compared with our own study. Six of their GHD patients had a $\mathrm{GH}$ response to Hexarelin below the limit, while the seventh patient was just above the borderline $(14.7 \mu \mathrm{g} / \mathrm{l})$. All non-GHD subjects, as identified by ITT, were correctly classified by the Hexarelin test. Similar to our results with GHRP-6, a test using Hexarelin alone for provocation of $\mathrm{GH}$ release had a high sensitivity and specificity for the diagnosis of severe GH deficiency.

Most groups studied GHS combined with GHRH for the diagnosis of $\mathrm{GH}$ deficiency in adults. In a recent multicenter study, Popovic and co-workers (9) investigated 125 adult patients with organic pituitary disease by performing an ITT and by testing with GHRP-6 $(1 \mu \mathrm{g} / \mathrm{kg})$ in combination with GHRH $(1 \mu \mathrm{g} / \mathrm{kg})$. The mean GH peaks during ITT (GHD group: $0.5 \mu \mathrm{g} / \mathrm{l}$; GS group: $14.3 \mu \mathrm{g} / \mathrm{l}$ ) were lower than in our study (GHD group: $1.3 \mu \mathrm{g} / \mathrm{l}$; GS group: $25.7 \mu \mathrm{g} / \mathrm{l})$. In contrast, their results of the GHRP-6 + GHRH test (GHD group: $4.1 \mu \mathrm{g} / \mathrm{l}$; GS group: $59.2 \mu \mathrm{g} / \mathrm{l}$ ) were virtually identical to our study (GHD group: $4.0 \mu \mathrm{g} / \mathrm{l}$; GS group: $54.7 \mu \mathrm{g} / \mathrm{l})$. Therefore, whereas results of an ITT may depend on specific conditions in the endocrine unit resulting in various degrees of hypoglycemia, the GHRP-6 + GHRH test appears to be less prone to such variations. By ROC curve analysis, Popovic et al. identified a cut-off of $15 \mu \mathrm{g} / \mathrm{l}$ for $\mathrm{GH}$ peaks as being the best threshold decision. Our own study suggests a cut-off of $<13 \mu \mathrm{g} / \mathrm{l}$ to identify GHD subjects. Although the study of Popovic et al. includes a larger number of patients, GH levels were measured in various centers using seven different $\mathrm{GH}$ assays. Different cut-off values may result from $\mathrm{GH}$ assay variations, indicating that each laboratory should establish its own criteria for normality of response using its own GH assay.

Some groups utilized GHS other than GHRP-6 in combination with GHRH for provocation of $\mathrm{GH}$ release. Gasperi and co-workers compared $\mathrm{GH}$ provocation by Hexarelin $(0.25 \mu \mathrm{g} / \mathrm{kg})$ combined with GHRH $(1 \mu \mathrm{g} / \mathrm{kg})$ with the results of an ITT in healthy subjects and 19 GHD patients (10). Analyzing the GHD patients, the authors found a mean $\mathrm{GH}$ peak of $2.6 \mu \mathrm{g} / \mathrm{l}$ during 
Hexarelin + GHRH testing. Normal GH peak response during Hexarelin + GHRH testing was defined by the first percentile limit established from healthy subjects. All GHD subjects but also some healthy subjects had GH peaks below $51.2 \mu \mathrm{g} / \mathrm{l}$, which results in a sensitivity of $100 \%$ but somewhat lower specificity.

All subjects in our study had peak values either 15 min or 30 min after administration of GHRP- 6 test or GHRP-6 + GHRH. In their larger study, Popovic et al. found only 24 subjects with GH peaks at $45 \mathrm{~min}$ or later. Apparently, peak values in these subjects were similar to values obtained at $30 \mathrm{~min}$ (9). Therefore, provocative tests using GHS may be limited to a maximum interval of $30 \mathrm{~min}$ without losing diagnostic information. The AUC was as good as GH peak values to classify GHD subjects but is more cumbersome to obtain and does not offer any diagnostic advantage, judged by the results of our study. Although IGF-I levels were lower in GHD patients compared with GS subjects, there was a significant overlap between the two groups. Five GHD subjects (50\%) are falsely classified as GH sufficient by IGF-I values, and one GS subject $(10 \%)$ is falsely classified as GHD. It has previously been demonstrated that circulating IGF-I levels do not provide a reliable marker of $\mathrm{GH}$ secretion in adults because they are greatly influenced by nutritional and metabolic status, IGF-I and IGF-binding protein-3 (IGFBP-3) being within the normal range in more than $60 \%$ of patients with GH deficiency $(11,12)$.

In summary, the results suggest that a test using GHRP-6 test or GHRP-6 + GHRH for provocation of $\mathrm{GH}$ release is as sensitive as an ITT for the diagnosis of adult GH deficiency. It remains to be seen if other GHS are as useful as diagnostic tools. Whereas most groups used GHS in combination with GHRH, we found a single GHS test as sensitive and specific. In contrast to the ITT, there are very few side effects and no obvious contraindications for such a test. It is generally recommended to generate normative values before a test is used for routine investigation. Cut-off limits should be established appropriate to that test. Therefore, further investigation of the GHRP- 6 test and the GHRP-6 + GHRH test are necessary, before they may be considered to replace the ITT.

\section{Acknowledgements}

We like to thank the medical staff of the endocrine unit for help in performing the various tests. We also thank
Lilly Deutschland $\mathrm{GmbH}$ for the generous support of this study.

\section{References}

1 Carroll PV, Christ ER, Bengtsson BA, Carlsson L, Christiansen JS, Clemmons D et al. Growth hormone deficiency in adulthood and the effects of growth hormone replacement: a review. Growth Hormone Research Society Scientific Committee. Journal of Clinical Endocrinology and Metabolism $1998 \mathbf{8 3} 382-395$.

2 Consensus guidelines for the diagnosis and treatment of growth hormone (GH) deficiency in childhood and adolescence: summary statement of the GH Research Society. Journal of Clinical Endocrinology and Metabolism 200085 3990-3993.

3 Bowers CY. Growth hormone-releasing peptide (GHRP). Cellular and Molecular Life Sciences $1998 \mathbf{5 4} 1316-1329$.

4 Howard AD, Feighner SD, Cully DF, Arena JP, Liberator PA, Rosemblum CI et al. A receptor in pituitary and hypothalamus that functions in growth hormone release. Science 1996273 974-977.

5 Nargund RP, Patchett AA, Bach MA, Murphy MG \& Smith RG. Peptidomimetic growth hormone secretagogues. Design considerations and therapeutic potential. Journal of Medical Chemistry $1998413103-3127$.

6 Kojima M, Hosada H, Date Y, Nakazato M, Matsuo H \& Kangawa $\mathrm{K}$. Ghrelin is a growth-hormone-releasing acylated peptide from stomach. Nature $1999 \mathbf{4 0 2}$ 656-660.

7 Ghiho E, Arvat E, Muccioli G \& Camanni F. Growth hormonereleasing peptides. European Journal of Endocrinology 1997136 $445-460$.

8 Korbonits M, Kaltsas G, Perry LA, Grossman AB, Monson JP, Besser GM et al. Hexarelin as a test of pituitary reserve in patients with pituitary disease. Clinical Endocrinology $1999 \mathbf{3 5 6}$ $369-375$.

9 Popovic V, Leal A, Micic D, Koppeschaar HP, Tores E, Paramo C et al. GH-releasing hormone and GH-releasing peptide- 6 for diagnostic testing in GH-deficient adults. Lancet $2000 \mathbf{3 5 6}$ 1137-11142.

10 Gasperi M, Aimaretti G, Scarcello G, Corneli G, Cisci C, Arvat E et al. Low dose hexalerin and growth hormone (GH)-releasing hormone as diagnostic tool for the diagnosis of GH deficiency in adults: comparison with insulin-induced hypoglycemia test. Journal of Endocrinology and Metabolism $1999 \mathbf{8 4} 2633-2637$.

11 Cuneo RC, Salomon F, McGauley GA \& Sonsken PH. The growth hormone deficiency syndrome in adults. Clinical Endocrinology $199237387-397$.

12 Hoffman DM, O'Sullivan AJ, Baxter RC \& Ho KK. Diagnosis of growth hormone deficiency in adults. Lancet $1994 \mathbf{3 4 3}$ 1064-1068.

Received 9 October 2001

Accepted 6 December 2001 